University of New Hampshire

University of New Hampshire Scholars' Repository

Law Faculty Scholarship

University of New Hampshire - Franklin Pierce

School of Law

$1-1-2009$

\title{
A Miscarriage of Juvenile Justice: A Modern Day Parable of the Unintended Results of Bad Lawmaking
}

Amy Vorenberg

University of New Hampshire School of Law, amy.vorenberg@law.unh.edu

Follow this and additional works at: https://scholars.unh.edu/law_facpub

Part of the Criminology and Criminal Justice Commons, Juvenile Law Commons, Law and Society Commons, Political Science Commons, Public Affairs, Public Policy and Public Administration Commons, and the Social Control, Law, Crime, and Deviance Commons

\section{Recommended Citation}

Amy Vorenberg, "A Miscarriage of Juvenile Justice: A Modern Day Parable of the Unintended Results of Bad Lawmaking," 12 MICH. CHILD WELFARE L. J. 17 (2009).

This Article is brought to you for free and open access by the University of New Hampshire - Franklin Pierce School of Law at University of New Hampshire Scholars' Repository. It has been accepted for inclusion in Law Faculty Scholarship by an authorized administrator of University of New Hampshire Scholars' Repository. For more information, please contact sue.zago@law.unh.edu. 


\title{
A Miscarriage of Juvenile Justice: A Modern-day Parable of the Unintended Results of Bad Lawmaking'
}

\author{
by Amy Vorenberg, Franklin Pierce Law School
}

"A story is only half told if only one side has been presented."

- Icelandic Proverb

The Problem of Media-driven Policy-making

Throughout American history, public opinion and the actions of our lawmakers have been swayed by tragic or sensational stories. At times, these actions have been well reasoned and proportional to the need for public safety and social control such as the workplace safety legislation passed in the wake of the 1911 Triangle Shirtwaist Factory fire in New York City in which 146 trapped garment workers perished. While legislative changes based on large scale tragedies are often warranted, politicians have also been known to capitalize on singular events to advance their agendas or demonize their opponents. This strategy was a key component of George H. W. Bush's successful presidential campaign of 1988 when he relentlessly criticized Massachusetts Governor Michael Dukakis for condoning a program that allowed the weekend furlough of Willie Horton-a lone case of a convicted murderer who escaped from the furlough program and later assaulted and raped a woman in Maryland. ${ }^{2}$

These sensationalized cases, due to the impact of 24-hour cable TV news coverage, increasingly create the context for public policy discussion. Stories about violent crime are a common feature of the local evening news, and their emotional nature can often create the hook politicians need to showcase their "tough on crime" agendas. Often anecdotal and lurid, stories of criminal misdeeds are widely used to convince the public of a need to create or change laws.

\section{A Sea Change in Juvenile Justice Policy}

A case in point is the public discussion of juvenile justice in the late 1980s and early 1990s. Articles from that time concerning juvenile justice policy almost always begin with a shocking story of a crime committed by a juvenile. Other stories published in the early 1990s warned of the rise of violent, depraved "superpredator" youths and sparked a nationwide wave of increasingly punitive laws aimed at juvenile crime. ${ }^{3}$ There has been scant media coverage, however, of the many juveniles who got caught in the wider net cast by this new legislation. There is little public discussion or thoughtful analysis in the mainstream media of the efficacy of these new "tough on crime" policies. Although their cases were minor and would have been settled quickly and confidentially in juvenile court, many juvenile offenders found themselves in the adult system. There they entered a kind of no-man's land where they were considered too old to be treated as children but were completely unprepared to fend for themselves in the adult penal system and ineligible for adult social programs, like housing assistance, upon release.

In this article, I examine the impact of a 1995 change in New Hampshire state law that lowered the age that a youth could be charged as an adult from 18 to 17 . The law was passed in the wake of two isolated but brutal juvenile murders with little examination of the empirical data. This article, therefore, points out the perils of making law by extrapolating from a few random, albeit attention-grabbing, events. 
Although New Hampshire is the focal point of this article, other states' stories are similar. The Michigan legislature responded to public attention on juvenile crime by amending its state juvenile code in 1996 and in so doing instituted one of the more punitive approaches to juvenile law. ${ }^{4}$ These changes were made despite the fact that violent crime, including juvenile violent crime, was on the decrease ${ }^{5}$

To demonstrate the counter-productive and perhaps damaging nature of this approach to governance, I will review juvenile crime rate statistics for the period in question, but it is my view that the impact of the data alone can be significantly enhanced by examining specific instances of the law's effect. If media stories are used to justify legislative actions, then the stories of those affected by the actions should similarly be useful in deciding if the change was warranted. I will go beyond the data and recount the story of Justin B., a young man whose arrest for simple underage drinking began a Kafka-esque descent into legal limbo and incarceration. This article will show that in New Hampshire, as in states all over the country, the statutory change was an overreaction prompted by sensationalized and anecdotal evidence. By looking at the events and influences that inspired New Hampshire's legislative changes, the consequences of the new law, and the effects it had on Justin B.'s life, I will show that the law not only fell far short of its intended goals, but possibly made the citizens of New Hampshire less safe and at great cost.

As one of the offenders who entered the adult system at 17, Justin B. got caught in the no-man's land I have described and consequently was pulled more deeply into a life of petty crime and substance abuse.

"I was 17 when I went to jail for the first time. Before I went to jail, I wasn't a violent person; I didn't fight. But I had to fight in jail. After I got out of jail, I'd flip out on people who gave me attitude, where before I would've ignored them."

\section{The New Hampshire Approach-All Emotion, No Reason}

Before we look more closely at the street-level impact of a delinquency age of 17 , let's review how this legislation came to be changed in New Hampshire. Criminal defendants are charged either as juveniles or adults. ${ }^{6}$ In most states youths are considered adults once they turn 18 , but there are a number of states that set the cutoff at a younger age. ${ }^{7}$ Many states, including New Hampshire, have a legal process by which children under the delinquency age charged with certain enumerated violent crimes can be certified as adults and charged as adults. ${ }^{8}$ Before 1995 , children age 18 or under were prosecuted as juveniles in New Hampshire. ${ }^{9}$ In 1995, the NH legislature passed a law that changed the definition of a "minor" from a person under the age of 18 to a person under the age of $17 .^{10}$

What prompted this change? In late 1987, a 14year-old boy murdered a 9-year old boy in the small town of Pittsfield, New Hampshire by shooting him in the head. The two children knew each other, and the body was discovered when the 14-year old agreed to show the police where he left the body. The gruesome crime was the subject of numerous stories in the media. Despite the shocking nature of the crime, the New Hampshire Attorney General's Office could not prosecute the case because the boy was too young to be considered for certification as an adult under the statute at the time. ${ }^{11}$

Ultimately, the perpetrator was prosecuted in juvenile court and received the maximum sentence of roughly three years at a youth detention facility- the number of years remaining until he turned 18 , when the juvenile system no longer had jurisdiction. There was no option to transfer him to adult court. ${ }^{12}$

New Hampshire has one of the lowest rates of homicide in the country, ${ }^{13}$ but, coincidentally, later the same year a 15-year-old was involved in the murder of a 5 -year-old. ${ }^{14}$

In the aftermath of these two terrible incidents, the New Hampshire legislature took up the cause of juvenile law reform. The State's attorney general, Stephen Merrill, had handled the prosecution of both murders. Frustrated that he was powerless to prosecute the teen defendants in adult court, Merrill championed a new law to lower to 13 the age at which juveniles accused of serious crimes could be certified by a court and treated as adults. The measure was adopted by the legislature in 1988 but limited to cases of murder, rape, and kidnapping. ${ }^{15}$ At the time, there were rumors that Attorney General Merrill proposed the change and took a public position on the matter to further his own political aspirations. ${ }^{16}$ Merrill denied the rumors, but eight months later, Merrill said that he would "not 
rule out" political office. ${ }^{17}$ In 1992, Merrill ran for governor and won. When Merrill began his reelection campaign two years later (the term of office in New Hampshire is two years), he made juvenile crime a focal point of his campaign. ${ }^{18}$ Following a "tough on crime" campaign strategy common in American politics, Merrill proposed a further change in the law, namely, to lower the age of delinquency for all crimes, not just violent crimes, from 18 to $17 .{ }^{19}$

Merrill and his allies in the legislature cited two reasons to support this change. First, they claimed there had been an increase in violent juvenile crime in New Hampshire. ${ }^{20}$ Second, they asserted that police officers were witnessing a rise in the number of illegal drug sales in the populous southern part of the state adjacent to the neighboring state of Massachusetts. The age of delinquency was 18 in New Hampshire versus 17 in Massachusetts, and so police representatives believed that juveniles were crossing the border specifically to undertake illicit drug transactions because they were safe in the knowledge that, if caught, they would face lighter penalties in juvenile court. ${ }^{21}$

\section{The Myth of Rising Juvenile Crime}

Although state and national statistics were readily available, proponents of the delinquency changes made little reference to them during legislative hearings on the new bill. Witnesses testified that there had been an increase in violent juvenile crime. ${ }^{22} \mathrm{Had}$ the legislature studied the available data, however, they would have found that juvenile violent crime in New Hampshire had leveled off or even started to decline. (Figure 1). In fact, the total number of violent crimes committed by juveniles fell 26 percent in 1994, from a peak in 1993 . The total number of violent crimes committed by 17 -year-olds, those that the new law was trying to impact, did rise from 1992 to 1994 but returned in 1995 to the same level seen in 1990. The total number of violent crimes committed by 17 -yearolds peaked at only 32, a small sample with which to make statistical assertions.

In short, one cannot draw a firm conclusion from the data concerning any trend toward higher crime rates; the variation in the numbers could just as easily be due to coincidence. The significant increase was among 15- and 16-year-olds, neither of which would have been affected by the new law.

Support for the legislation rested largely on anec-
Figure 1: NH Arrests for Violent Crime by Juveniles ${ }^{23}$

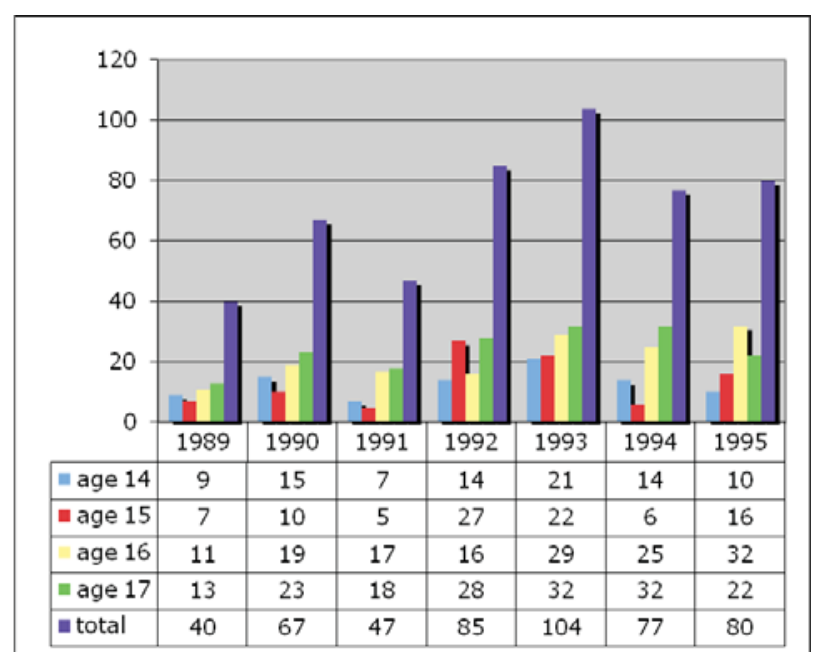

Figure 2: Total Arrests of New Hampshire 17-Year-Olds 29

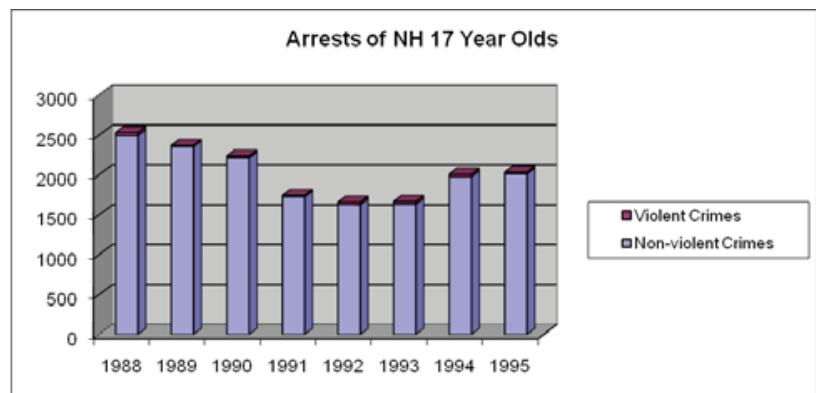

dotal information. Several chiefs of police and other law enforcement officers testified or wrote letters in support of lowering the age of delinquency. ${ }^{24}$ One police chief appearing on behalf of the New Hampshire Chiefs Association testified that "the increase in the incidence of violent crime committed by young adults in our society is a trend which is unacceptable. And demands new thinking." 25

The governor stressed the need to distinguish between the juvenile who makes a "stupid mistake" and the young person who is "in fact a career criminal." 26 Other witnesses who testified in support of the bill assured concerned legislators that the new law was meant for the serious offenders and that discretion on the part of judges and prosecutors would protect 17year-olds accused of minor offenses. ${ }^{27}$

The new law was proposed specifically to address the upsurge of violent crime by 17 -year-olds by designating them as adults. However, there was no upsurge in this particular category. In fact, the overall rate of arrests of 17 -year-olds was trending down. (Figure 2). The data 
show that the number of arrests declined from 1988 to 1992, and the increased numbers of 1993 and 1994 did not reflect a significant upward trend. Indeed, total arrests during that period never approached those seen in 1988, long before the supposed spike in juvenile crime. ${ }^{28}$

Figure $3^{30}$

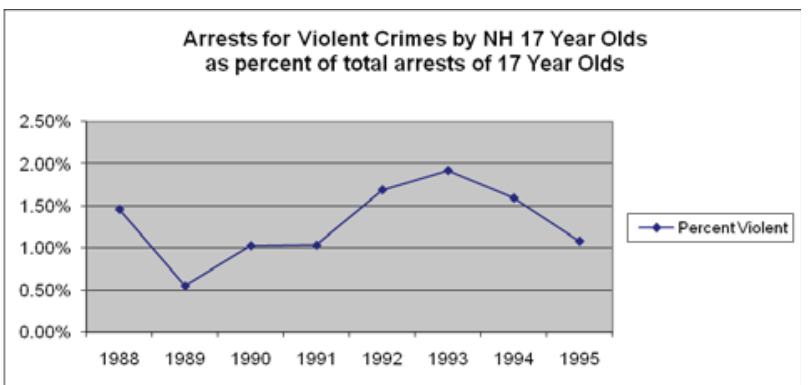

Perhaps even more significant, the rate of violent crime among 17-year-olds was decreasing. (Figure 3)

The national data also did not demonstrate a spike in violent youth crime. Although there was an increase in the rate of arrests for youth violent crime, the increase occurred throughout all age brackets. Notably, the increase in arrests for violent crime occurred equally in the juvenile age bracket (13 to 17 ) and in the young adult bracket (18 to 24). ${ }^{31}$ Between 1992 and 2000, there was a significant decline in violent crime nationally, and this was largely due to a decrease in arrests of juveniles for violent crime. ${ }^{32}$

The increase in juvenile violent crime in the late 80 s and early 90s mirrored a general increase in violent crime nationwide. ${ }^{33}$ The overall violent crime rate continued on an uphill rise until 1993 and then gradually declined until it leveled off in $2000 .^{34}$

The notion that there was a spike in juvenile violent crime in the late 1980s may have been as much a response to fear, driven both by media and politicians, as it was based on an actual rate of violent crime. ${ }^{35}$ Indeed, the public's perceptions that juvenile crime was on the rise continued even as the juvenile crime rate declined. ${ }^{36}$ Although the dire predictions about teenage "super-predators" were never realized, between 1992 and 199747 states and the District of Columbia made their juvenile justice systems more punitive. ${ }^{37}$ As states shifted their laws to make juveniles more accountable in order to decrease crime, the very juveniles affected by the laws were responsible for a substantial shift downward in the crime rate, due to forces largely unrelated to any legislative initiative. Theories abound about the cause of the downward decline of juvenile crime in the mid-1990s and include a more robust job market, the growth of community policing, market and policy changes dealing with illegal drugs and firearms, and even the legalization of abortion 20 years earlier. ${ }^{38}$ The cause and effect of the more punitive laws do not appear to be a leading factor in the decline, as the shift in the law came after the crime rate had already stabilized and begun a downward trend.

Moreover, in New Hampshire, the law lowering the age for juveniles was essentially duplicative. Violent juvenile offenders could already be treated as adults if they were so certified by a court. ${ }^{39}$ Certification required a prosecutor to demonstrate through a multifactor test that the offender warranted adult treatment. ${ }^{40}$

Figure 4: National Arrests For Youth Violent Crime 1989-1995

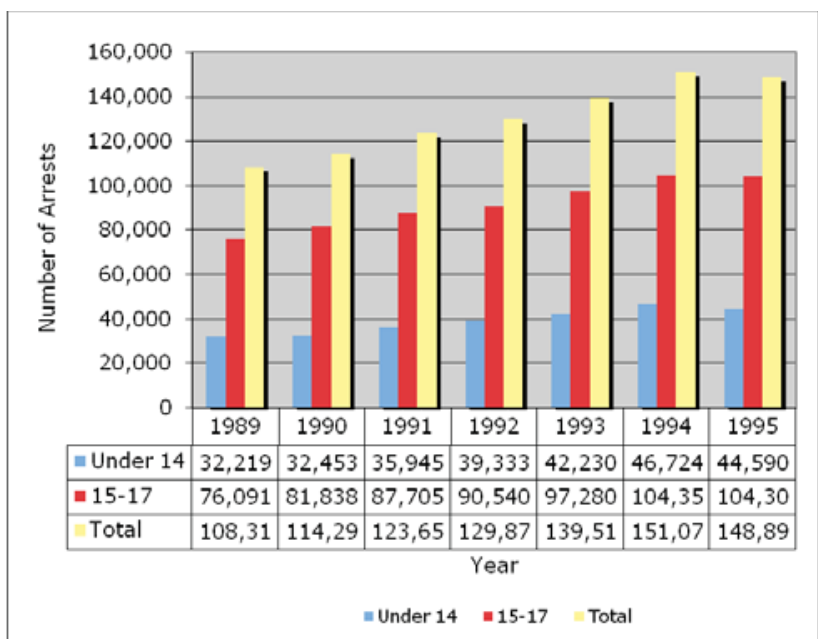

\section{The Evidence That Juveniles Were Coming into $\mathrm{NH}$ to Sell Drugs}

Proponents of the new law took the position that juveniles from Massachusetts were coming over the border to sell drugs, safe in the knowledge that they could only be tried as a juvenile if they were caught. Statistics provided to the House Committee showed that indeed there had been an increase in arrests of juveniles selling drugs between 1990 and $1995 .{ }^{41}$ These statistics showed that in 1993 and 1994, over half of the juveniles arrested for drug sales in New Hampshire were from outside the state. These youths were 
primarily from Lawrence, Massachusetts, an industrial city just south of the New Hampshire border. ${ }^{42}$ However, the increase in drug arrests occurred in Massachusetts as well, and in Lawrence in particular. ${ }^{43}$ Lawrence was one of two New England distribution points for the heroin trade in the 1990s, and the city saw a significant increase in drug usage between 1993 and $1999 .{ }^{44}$ The increase in arrests of out-of-state juveniles in 1993 and 1994 was quite possibly due to the surge in heroin usage just below the border and did not necessarily have anything to do with the age at which a juvenile could be arrested in New Hampshire.

Thus, the data about juvenile crime did not support the particular change that ultimately passed the New Hampshire legislature. What resulted were reforms in a system that was not necessarily "broken." The reforms have nevertheless endured, and there are indications that they have created more problems than they have fixed.

\section{Justin B}

Justin B. ${ }^{45}$ is a tall, dark-haired, well-spoken 21year-old. He is well put together, clean-shaven, neatly dressed, and healthy. The only mark of his repeated incarcerations were two missing teeth lost in a fight. He spoke clearly and thoughtfully about his past. Justin went to jail for the first time when he was seventeen. He was charged with underage drinking, and because of a change in New Hampshire's law that lowered the age of delinquency from 18 to $17,{ }^{46}$ Justin was charged as an adult. Ironically, Justin was too young to drink alcohol legally, but old enough to handle an adult correctional facility. This was Justin's first time in the criminal justice system. When he went in front of the judge to have his bail set, Justin was released on the condition that he "obey his parents."

Justin's path into the "no-man's land" between the juvenile and the adult system started with just the sort of "stupid mistake" — underage drinking — that proponents of the bill had said would not be covered by the bill.

Justin grew up in a trailer park with his brother, sister, mother, and father. He describes himself as a quiet child, "a mother's boy" who got into trouble for small things like not cleaning his room. He had a difficult relationship with his father, who had little tolerance for any misbehavior, and would punish
Justin by making him stand in a corner facing the wall for 12 hours at a time. Justin describes his relationship with his mother as close, and she apparently often protected Justin from his father's anger.

His two siblings were popular, while Justin was more of a loner. In his early teens, Justin's aunt and uncle died, and Justin's mother took in their young children. Over the next few years, Justin's home life unraveled. His mother began using drugs and went to rehab. His father kicked Justin out of the house, and he went to stay with relatives.

At age 16, Justin discovered alcohol and remembers that he "loved it." The feeling he got when he drank allowed him to "be someone he couldn't be before." When he was drinking, he felt socially connected. At 17, Justin left his aunt and uncle and moved back home. Eventually he and his father began to argue again, and he was again asked to leave. With nowhere to live- - he was too young to go to a shelter but too old to be treated as a juvenile-Justin started living in his car. It was there that his sister spotted him drinking one night and called the police. The police arrested Justin for underage drinking. At his bail hearing, the judge allowed him to be free but required that he live with his parents and "obey them."

Figure 5

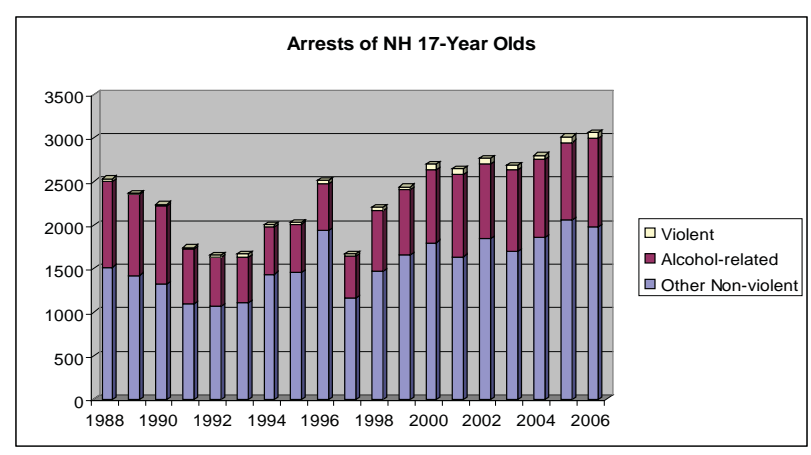

What Happened in New Hampshire after the Bill Passed

The lower age at which a child could be treated as an adult came into effect in January 1996. The claim that the law would somehow curb violent crime committed by 17-year-olds has not turned out to be the case. As Figure 5 demonstrates, there was no significant change in the number of violent crime arrests for 17-year-olds. These teenagers continued to com- 
mit violent crime at roughly the same rate, the only difference being that they were now treated as adults instead of juveniles. In fact, between 1996 and 2005, there has been a steady climb in the number of violent crime arrests of 17 -year-olds (Figure 5). ${ }^{47}$

Even more significant are the large number of arrests for non-violent crimes, in particular alcoholrelated arrests. ${ }^{48}$ All of these lesser offenders have been processed through the adult court, where their access to treatment, school support, and counseling programs is limited if not non-existent. In juvenile court, judges have the ability to bring in social workers, school representatives, and even parents. Thus, the overall upshot of lowering the age to 17 has been that many youths who have committed "stupid mistakes," such as underage drinking, end up in the stigmatizing and more punitive adult system - a system where they lose their privacy and quite probably access to treatment that would divert them out of the system at an early age.

In 2002, the NH legislature took up a proposal to raise the age back to $18 .{ }^{49}$ Legislators acknowledged that the original goals of the bill had not been accomplished and that the claims supporting the bill had been overblown or exaggerated. ${ }^{50}$ Lowering the age to 17 had, it turned out, many unintended or collateral negative consequences. For example, incarcerated 17-year-olds in need of medical care had to get their parents' permission to receive treatment. Seventeenyear-olds discharged from a juvenile facility without a place to live ended up homeless, and shelters could not legally take them in. They were unable to obtain food stamps, sign leases, or go on welfare. ${ }^{51}$ Recent developments in science and brain imaging strongly suggest that the adolescent brain's inability to make adult-like decisions presents mitigating factors that should impact policy on consequences and punishment for crimes. ${ }^{52}$

In addition to the many other negative consequences of the bill, it is likely that, as Figure 5 above shows, lowering the age to 17 caused more crime then it deterred. Although there are no specific studies in New Hampshire, there have been numerous studies in other jurisdictions. ${ }^{53}$ The overall conclusion of these studies is that processing juveniles in the adult system increases rates of violence among the young offenders. ${ }^{54}$ Moreover, the type or length of sentence does not seem to make a difference; the fact that juveniles are processed in adult versus juvenile court increases the likelihood of reoffending. ${ }^{55}$ Explanations for this are numerous. The prevailing view is that punitive consequences instead of rehabilitative treatment end up influencing youthful offenders to commit more, rather then less, crime. In the midst of their "formative" years, these adolescents are easily swayed by their environment. ${ }^{56}$

In general, all of the studies done to date indicate that transferring a juvenile to adult court increases the chances of recidivism. ${ }^{57}$ This is true even when juveniles are not incarcerated, but go on probation. ${ }^{58}$ Moreover, in at least one study, the recidivism rate for juveniles who commit violent crimes is high -24 percent of transferred juveniles, compared with 16 percent of retained juveniles. ${ }^{59}$

Youths who exhibit delinquent behavior likely have social deficiencies and lack healthy human bonds and structure in their environment. Putting 17-year-olds through the adult process ultimately exposes malleable and easily influenced young people to more powerful, often seductive forces. Youths in adult versus juvenile facilities are left to their own devices where they congregate with other inmates as opposed to a juvenile facility where staff is more involved with residents. ${ }^{60}$ This was certainly the experience Justin had.

\section{Justin}

Justin went to jail for the first time when he was 17. After his initial arrest for alcohol possession, Justin returned home. He had a few more run-ins with police over alcohol possession. He was arrested for possession of marijuana at school. Initially, he received a summons for the possession, but when his parents found out about the charge, they fought, and ultimately had Justin's bail revoked. Still only 17, he stayed in a county correctional jail for three months. The place was loud and scary, he recalls. As soon as he fell asleep, other inmates threw wet toilet paper at him. Although the correctional officers ignored him, an older inmate, who said that Justin reminded him of his own son, took Justin under his wing and from then on, the other inmates left him alone. He was offered no treatment and no education. He remembers that it was during this time that he first felt depressed. He had been lonely before, but never depressed.

After his release, Justin went back to live with his parents. He took two full-time jobs and tried to "do the right thing," at least for two months. Before long, 
he started to argue with his parents again, and they called his probation officer. More rules were instituted, but eventually, his parents kicked him out, his probation officer violated him, and he returned to jail. Justin recalls that this time he felt more comfortable in jail. He was released the day before his $18^{\text {th }}$ birthday, so he was able to go into a homeless shelter this time. $\mathrm{He}$ worked at night and went to school during the day.

This time, Justin's undoing started when he connected with some friends he had made while in jail. They were a little older than he and into drinking. It was an incident with "friends" from jail that led to Justin's broken front tooth. At 18, some of these "friends" jumped Justin, robbed him, tied him up, and locked him in the trunk of a car. He was able to escape because the car was equipped with a child safety lock.

For the next couple of years, Justin went in and out of jail. He went into an alcohol treatment program, but he did not take the treatment "seriously." He started using heroin before his $20^{\text {th }}$ birthday, and at that point he "stopped caring." Drinking and doing heroin helped him cope with feeling alone. His friends from jail, for the most part, provided his only social connection.

By his $21^{\text {st }}$ birthday, Justin had been arrested more than 40 times and convicted at least 10 times. All of the offenses were related to his drinking-just the kinds of "stupid mistakes" that the original proponents of the bill promised it would not cover. Justin spent his $21^{\text {st }}$ birthday in jail. At the very least, he said, when he got out he would no longer be arrested for underage drinking.

\section{The Economics}

Transferring juveniles to the adult system shifts financial responsibility. Whether it is more or less expensive to treat 17-year-olds as adults is a subject of debate. On the one hand, rehabilitative and community services for adolescents can be very costly. Treating 18-year-olds as adults is costly if they are in jail, but if they are not in jail, the overall costs go down because the probation services offered are not as extensive as they would be if rehabilitative services were offered. However, the long-term costs of treating juveniles as adults can end up costing much more because of all the residual effects of failing to provide services and support during a formative period of a child's development, incarceration and the overall stigma take an emotional toll on a youth. ${ }^{61}$ Because juvenile cases are more carefully managed and individ- ualized they are more expensive, but it is those same reasons that likely lead to fewer juveniles coming back into the system.

In New Hampshire, proponents of raising the age when a juvenile goes into the adult system back to 18 have tried and failed to get a bill passed almost yearly since 1995 . In 2006, the legislative committee considering the change heard testimony that the state juvenile detention facility was under capacity, but that because of fixed costs, the facility was essentially losing money. ${ }^{62}$ States such as New York and Wisconsin are considering raising the age back based largely on the increased costs (both fiscal and societal); Connecticut recently passed legislation raising the age back to $18 .{ }^{63}$

Treating juveniles more punitively was, essentially, an over-reaction led by politicians and lawmakers who were pandering to voters' media-driven fears about juvenile crime. The passage of time and a closer look at the real data demonstrate that the fears were not justified, and that juvenile crime was not surging. Public opinion on the issue has shifted and now leans towards treating juveniles as juveniles. ${ }^{64}$ Indeed, according to one poll, public opinion supports the notion of rehabilitation and treatment of juveniles as a means to save tax dollars. ${ }^{65}$ Similarly, the public seems to recognize that incarcerating youths leads to more, not less, crime. ${ }^{66}$

Justin's story is a powerful illustration of the failure of the law-as powerful as the anecdotes used by the proponents to get the bill passed. More powerful perhaps because unlike the few violent crimes that led legislators to change the law, the stories of youths like Justin are numerous. One need only look at the number of youths charged as an adult with crimes like alcohol possession (Figure 5) to get a sense of how many were affected by the law.

\section{Justin Today-at 21}

After being released from the county correctional facility, Justin is homeless. He is staying at a homeless shelter, eating at a soup kitchen, and looking for work. Without a cell phone or an address, giving prospective employers contact information is impossible. He goes to AA meetings and tries to stay away from the people he knows will get him back into drugs and alcohol. He has no real job skills and a very meager support system. Nevertheless, he is optimistic. He feels as though he can do it this time. He wants to go to college (he got his GED in jail) and become a drug and alcohol counselor. (-) 
Professor Amy Vorenberg teaches legal skills and criminal law at Franklin Pierce Law School in Concord, New Hampshire. Before becoming a professor, she was a prosecutor in New York City and in New Hampshire. In 1993, she left prosecution and started the Criminal Practice Clinic at Franklin Pierce. The clinic provides legal assistance to indigent criminal defendants. She directed the clinic until 1997;since leaving the clinic, she has been teaching at Franklin Pierce.

\section{Endnotes}

1 I extend my thanks to Roger Wellington, Professor Kimberly Kirkland, Eliza Vorenberg and Elizabeth Vorenberg for their input, support and editing. I am deeply appreciative of the time Justin took to share his experiences with me. Finally, to my research assistant, Caroline Schleh, my sincere thanks for the many hours, the enthusiasm and the interest in this project.

2 Another example is the case of Terry Schiavo, a comatose Florida woman whose husband battled with his in-laws to remove his wife's feeding tube. After widespread publicity, the case lead to the passage of legislation in the U.S. congress called "The Palm Sunday Compromise" that allowed the matter to be transferred to federal court.

3 James T. Campbell, Teen crime wave on rise; Recent slayings offshoot of increase in violence, The Houston Chronicle, Sept. 20, 1991, at A1.; David A. Avila, Juvenile Crime Rising Sharply, Los Angeles Times, Aug 25, 1992 at B1; Fred Robinson, Combating Youth Crime; Getting Tough is Necessary but it's Not Enough, The Atlanta Journal and Constitution, July 29, 1994 at A14. The term "super-predator" was promoted by John Dilulio, Jr., a criminologist who warned of a surge in juvenile violence. The Coming of the Super Predators, The Weekly Standard, November 27, 1996 at 23.

4 Mich.Comp.Laws.Ann .Sec. 712A.2; Frank E. Vandercourt, William E. Ladd, The Worst of all Possible Worlds: Michigan's Juvenile Justice System and International Standards for the Treatment of Children, 78 U. of Detroit Mercy L. Rev. 203, 227 (2001).

5 Michigan State Police Uniform Crime Reports, 1997.

6 Treating juveniles in a separate but parallel system dates back to 1899 , when Illinois developed the first Juvenile Court.

7 State Statutes Define Who is Under the Jurisdiction of Juvenile Court, Juvenile Offenders and Victims: 2006 National Report (DOJ, Office of Juvenile Justice and Delinquency Prevention) at 103.

8 N.H. Rev. Stat. \$ 628:1(2002) (Children age 13 or older may be charged for certain offenses including murder, rape and kidnapping).

$9 \$ 169-B: 2$.
$10 \$ 169-B: 2$.

11 Id.

$12 \$ 169$.

13 http://www.disastercenter.com/crime/nhcrime.htm.

14 N.H. Judge Rules on Youth's Trial, Bos. Globe May 19, 1988 , at 30.

15 N.H. Rev. Stat. $\$ 628: 1$.

16 Norma Love, N.H. Foes Question How Juvenile Law to be Carried Out, Bos. Globe, May 13, 1988, at 21 (Merrill accused of "stirring up lawmakers' emotions to attract publicity for an eventual political career. Merrill denies he plans to run for office.").

17 Id.; Laura Kiernan, Attorney General in N.H. Quits, Merrill Prepares to Open a Private Law Firm, Bos. Globe, Jan. 11, 1989 at 17. ("Merrill, who now lives in Manchester, yesterday did not rule out a political future.").

18 Jordan Rau, Reform is on the Way, But Will it Work? Conc. Mon., Feb 15, 1995 at A-1. ("As [Governor Merrill] campaigned for re-election last year, he said, he became convinced that young people do not respect the juvenile system.").

19 In New York State's 1978 race for governor, Hugh Carey proposed similar changes in juvenile law. At the time, he was facing a close race for reelection and he had been accused of being soft on crime. In response he proposed the most punitive delinquency laws in the country. The Changing Borders of Juvenile Justice, Fagan et al page 354; Proposition 21, the California initiative that expanded criminal jurisdiction of juveniles was widely believed to be the result of Governor Pete Wilson's ambition to become a Republican presidential candidate. Elizabeth Scott \& Laurence Steinberg, Rethinking Juvenile Justice 103 (Harvard University Press 2008).

20 Changing the Age for Application of the Delinquency Provisions from 18 to 17: Hearing on $H B 52$ Before the $H$. Comm. on Corrections and Criminal Justice, 1995 Leg. Sess. (N.H. 1995). (Testimony of Governor's Counsel, Tina Nadeau).

21 Changing the Age for Application of the Delinquency Provisions from 18 to 17: Hearing on HB 52 Before the $H$. Comm. on Corrections and Criminal Justice, 1995 Leg. Sess. (N.H. 1995). (Rep. Donna Sytek).

22 Id. (Statement of William Lyons, Attorney General's Office).

23 State of NH Dept. of Safety - Uniform Crime Reporting.

24 Changing the Age for Application of the Delinquency Provisions from 18 to 17: Hearing on H.B. 52-FN-L, Before the H. Comm. on Corrections and Criminal Justice 1995, Leg. Sess. (Minutes).

25 H.B. 52-FN-L (Testimony of Chief Stephen Monier, Chief of Goffstown, NH police Department). 
26 Public Hearing on HB 52 March 7 1995, Minutes (Testimony of NH Gov. Stephen Merrill).

27 Id. (Testimony of William Lyons, NH Asst. Atty. Gen'l).

28 As the bill to lower the age left the House committee on its way to a vote, the minority report, supported by 7 members of the 21 - member committee was filed. Questioning the governor's stated intent to crack down on juvenile violent offenders, the report noted that only 2.4 percent of juvenile offenders were violent. Changing the Age for Application of the Delinquency Provisions from 18 to 17: Committee Report on H.B. 52-FN-L, Before the H. Comm. on Corrections and Criminal Justice, 1995 Leg. Sess.

29 New Hampshire Uniform Crime Reports.

30 Id.

31 A 1999 article posted by the Urban Institute noted that the public outcry about the increase in violent juvenile crime in the late 1980s and early 1990s was based on misperceptions. The data reflect an increase in arrests for both juveniles and youth adults (ages 18 to 23). "This is clear if we examine actual increases in the number of murder arrests rather than the rate of murder arrests. The entire increase in murder arrests between 1980 and 1994 was due to growth in arrests among young people, but adults (ages 18-23) and juveniles (ages 13-17) were equally responsible for the increase. www.urban.org/ publications/410402.html\#anim2_return (May 1999).

32 Jeffrey Butts and Jeremy Travis, Urban Institute Justice Policy Center Research Report, The Rise and Fall of American Youth Violence 1980-2000 p. 3 (2002).

33 US. Dept. Just., FBI, Crime in the United States (Sept. 2007). Retrieved (Dec. 2008) from http//www.fbi.gov/ ucr/cius2006/.

$34 \mathrm{Id}$.

35 Elizabeth Scott and Laurence Steinberg suggest that the juvenile crime policy of the early 1990s was driven by a perceived threat that was reinforced by politicians, the media, and the public resulting in an exaggerated response. Elizabeth Scott, Jeffrey Butts, Rethinking Juvenile Justice, p. 10.

36 Mark Solar, Public Opinion on Youth, Crime and Race: A Guide for Advocates. Building Blocks for Youth. http:// www.buildingblocksforyouth.org/advocacyguide.pdf., ( 2001) p. 12.

$37 \mathrm{Id}$. at 13.

38 Jeffrey Butts and Jeremy Travis, Urban Institute Justice Policy Center Research Report, The Rise and Fall of American Youth Violence 1980-2000 p. 3 (2002); Steven Levitt, Stephen Dubner, Freakonomics, 4 (William Morrow ed., Harper Collins (2005). (Suggesting that the legalization of abortion in 1973 led to fewer births of children born into adverse circumstances who would be more likely to grow up and engage in criminal behavior).
$39 \$ 169$

40 Id.

41 Changing the Age for Application of Delinquency Provisions From 18 to 17: Hearing on HB-52-FN-LOCAL Before The Senate Committee on Judiciary, 1995 Leg. Sess. NH 1995). Statement of Asst. Atty. Gen'l William Lyons-Attachment \#2.

$42 \mathrm{Id}$.

43 http://www.usdoj.gov/ndic/index.htm at 8 .

44 Id. at 1.

45 Not his real name.

46 Delinquent Children, 12 N.H. Rev. Stat. Ann. \$169B:2 (2002).

$47 \mathrm{NH}$ UCR.

48 "Alcohol related" arrests include arrests for Driving Under the Influence, Drunkenness and Liquor Law Violations.

49 Relative to raising the age of minority for purposes of juvenile delinquency proceedings from 17 to 18 years of age. Hearing on HB-179-FN Before The House Finance Committee, 2002 Leg. Sess. NH 2002). The bill was ultimately defeated. Similar legislation failed to pass almost every year since.

50 Id. Testimony of State Representative David Bickford.

51 Relative to raising the age of minority for purposes of juvenile delinquency proceedings from 17 to 18 years of age. Hearing on HB 179 Before House Finance Committee, 2002 Leg. Sess. NH 2002). (Statement of Cynthia Herman representing Child and Family Services).

52 See Kevin W. Saunders, A Disconnect Between Law and Neuroscience: Modern Brain Science, Media Influences, and Juvenile Justice, 2005 Utah L. Rev. 695 (2005).

53 Angela McGowan et al., Effects on Violence of Laws and Policies Facilitating the Transfer of Juveniles from the Juvenile Justice System to the Adult Justice System: A Systematic Review, 32 Am J Prev. Med Issue 4 S7-S28 (April 2007) (compiling and evaluating data from studies based on New York City, Minnesota, Florida, Pennsylvania and Washington).

54 Id.

55 Donna Bishop \& Charles Frazier, Consequences of Transfer in The Changing Borders of Juvenile Justice; Transfer of Adolescents to the Criminal Court, 260-261 (Jeffrey Fagan, Franklin E. Zimmer, eds., U. Chicago Press 2000).

$56 I d$. at 263 (Bishop and Frazier's comprehensive review of the data regarding effects of juvenile transfer to adult court includes interviews with offenders who were prosecuted in adult court. The youths experienced the court process "not so much as a condemnation of their behavior as a condemnation of them"). 
57 Richard E. Redding, Juvenile Transfer Laws: An Effective Deterrent to Delinquency? OJJDP Juv. Jus. Bulletin Aug. 2008 at 6 . This article provides a thorough summary of the studies done to date on recidivism rates among juveniles who have been transferred to adult court.

58 Id.

59 Id.

60 Donna Bishop \& Charles Frazier, Consequences of Transfer, supra at 257.

61 See Scott\& Steinberg, Rethinking Juvenile Justice, supra note 20 at 219-220.

62 Including Persons 17 Years Old in the Juvenile Justice System: Hearing on HB 627-FN Before the H. Comm. On Finance, 2006 Leg. Sess. (N.H. 2006) (Rep. David Bickford).
63 C.G.S.A. $\$ 46 b-120$ (2007).

64 Barry Krisberg, Susan Marchionna, Attitudes of U.S. Voters toward Youth Crime and the Justice System, Nat'l. Council on Crime and Delinquency, Feb. 2007. (Reporting on a Zogby International poll about American attitudes toward our nation's response to youth crime).

$65 \mathrm{Id}$. at 3 (Over 80 percent of respondents believe that spending on enhanced rehabilitation services for youth in the juvenile justice system will save tax dollars in the long run. In comparison, only 1 in 7 (14 percent) disagrees).

$66 I d$. at 4. 